UDC: 538.9

\title{
Effect of annealing on dislocation structure parameters of ultrafine-grained copper: comparative study by acoustic and x-ray methods
}

\author{
P.P. Pal-Val, I.S. Braude, L.N. Pal-Val, V.G. Geidarov \\ B. Verkin Institute for Low Temperature Physics and Engineering NAS of Ukraine, 47 Nauki Ave., 61103 Kharkov, Ukraine \\ E-mail: palval@ilt.kharkov.ua
}

ORCID: 0000-0002-3287-973X

DOI: $10.26565 / 2222-5617-2019-30-02$

The acoustic spectroscopy method and X-ray diffraction analysis were used to study the effect of severe plastic deformation (SPD) and subsequent annealing on the parameters of the dislocation structure of ultrafine-grained (UFG) FRTP (Fire Refining Tough Pitch) copper. To this end, the effect of SPD and subsequent annealing on the main parameters of the low-temperature Bordoni acoustic relaxation was studied in detail. Annealing was performed in the temperature range $90-430{ }^{\circ} \mathrm{C}$, including the primary crystallization temperature of highly deformed copper $T_{\text {ann }} \approx 135{ }^{\circ} \mathrm{C}$. For all states of the samples, the estimates of the density of mobile dislocations $\rho_{\mathrm{m}}$, which contribute to the low-temperature dynamic relaxation, are obtained. Annealing leads to the decrease in the dislocation density from $\rho_{\mathrm{m}} \approx 1.7 \cdot 10^{12} \mathrm{~m}^{-2}$ to $\rho_{\mathrm{m}} \approx 1.5 \cdot 10^{11} \mathrm{~m}^{-2}$. In addition to the dislocation density, an estimate of the 1 st order Peierls' stress $\tau_{\mathrm{P}}=19 \mathrm{MPa} \approx 2.5 \cdot 10^{-4} G(G-$ shear modulus $)$ was also obtained from the acoustic measurements. In parallel with the acoustic measurements, the parameters of the dislocation structure of the samples were studied by X-ray diffraction. The values of the lattice parameter, the values of microdeformation, the average size of the coherent scattering region (CSR), and also the average density of dislocations were obtained. It turned out that the X-ray density of dislocations is two orders of magnitude higher than the values obtained from acoustic measurements. At the same time, the data on the effect of annealing obtained by both methods are in qualitative agreement with each other; in particular, a decrease in the dislocation density of the same order of magnitude is observed.

Keywords: severe plastic deformation, ultrafine-grained metals, acoustic spectroscopy, X-ray diffraction, low temperatures.

\section{Вплив відпалу на параметри дислокаційної структури ультразернистої міді: порівняльне дослідження акустичним та рентгенівським методами

\author{
П.П. Паль-Валь, І.С. Брауде, Л.Н. Паль-Валь, В.Г. Гейдаров \\ Фізико технічний інститут низьких температур ім. Б.І. Вєркіна НАН Украӥни, пр-т Науки 47, 61103 Харків, Украӥна
}

Методами акустичної спектроскопії та рентгеноструктурного аналізу вивчено вплив інтенсивної пластичної деформації (ІПД) і подальшого відпалу на параметри дислокаційної структури ультрадрібнозернистої (УД3) FRTP (Fire Refining Tough Pitch) міді. 3 цією метою детально вивчено вплив ІПД і наступного відпалу на основні параметри низькотемпературної акустичної релаксації Бордоні. Відпал проводився в інтервалі температур 90 - $430{ }^{\circ} \mathrm{C}$, що включає в себе температуру первинної кристалізації сильнодеформованої міді $T_{\mathrm{ann}} \approx 135{ }^{\circ} \mathrm{C}$. Для всіх станів зразків отримані оцінки щільності рухливих дислокацій, що дають внесок в низькотемпературну динамічну релаксацію. Відпал призводить до зменшення щільності дислокацій від значень $\rho_{\mathrm{m}} \approx 1.7 \cdot 10^{12} \mathrm{M}^{-2}$ до $\rho_{\mathrm{m}} \approx 1.5 \cdot 10^{11} \mathrm{M}^{-2}$. Окрім щільності дислокацій, 3 акустичних вимірювань отримана оцінка напруги Пайерлса I роду $\tau_{\mathrm{P}}=19 \mathrm{MPa} \approx 2 \cdot 5 \cdot 10^{-4} G$ ( $G$ - модуль зсуву). Паралельно 3 акустичними вимірами, проводилося дослідження параметрів дислокаційної структури зразків методом рентгенівської дифракції. Були отримані значення параметра решітки, значення мікродеформації, середній розмір області когерентного розсіювання (ОКР), а також середня щільність дислокацій. Виявилося, що рентгенівська щільність дислокацій на два порядки перевищує значення, отримані з акустичних вимірювань. У той же час дані щодо впливу відпалу, отримані обома методами, якісно узгоджуються між собою, зокрема, спостерігається таке ж по порядку величини зменшення щільності дислокацій.

Ключові слова: сильна пластична деформація, ультразернисті метали, акустична спектроскопія, рентгенівська дифракція, низькі температури. 


\title{
Влияние отжига на параметры дислокационной структуры ультразернистой меди: сравнительное исследование акустическим и
} рентгеновским методами

\author{
П.П. Паль-Валь, И.С. Брауде, Л.Н. Паль-Валь, В.Г. Гейдаров \\ Физико технический институт низких температур им. Б. Веркина НАН Украинь, пр-т Науки 47, 61103 Харьков, Украина
}

Методами акустической спектроскопии и рентгеноструктурного анализа изучено влияние интенсивной пластической деформации (ИПД) и последующего отжига на параметры дислокационной структуры ультрамелкозернистой (УМЗ) FRTP (Fire Refining Tough Pitch) меди. С этой целью детально изучено влияние ИПД и последующего отжига на основные параметры низкотемпературной акустической релаксации Бордони. Отжиг производился в интервале температур $90-430$ ${ }^{\circ} \mathrm{C}$, включающем в себя температуру первичной кристаллизации сильнодеформированной меди $T_{\text {ann }} \approx 135{ }^{\circ} \mathrm{C}$. Для всех состояний образцов получены оценки плотности подвижных дислокаций, дающих вклад в низкотемпературную динамическую релаксацию. Отжиг приводит к уменьшению плотности дислокаций от значений $\rho_{\mathrm{m}} \approx 1.7 \cdot 10^{12} \mathrm{M}^{-2}$ до $\rho_{\mathrm{m}} \approx$ $1.5 \cdot 10^{11} \mathrm{M}^{-2}$. Кроме плотности дислокаций, из акустических измерений получена оценка напряжения Пайерлса I рода $\tau_{\mathrm{P}}=19 \mathrm{MPa} \approx 2 \cdot 5 \cdot 10^{-4} G(G$ - модуль сдвига). Параллельно с акустическими измерениями, проводилось исследование параметров дислокационной структуры образцов методом рентгеновской дифракции. Были получены значения параметра решетки, значения микродеформации, средний размер области когерентного рассеяния (ОКР), а также средняя плотность дислокаций. Оказалось, что рентгеновская плотность дислокаций на два порядка превышает значения, полученные из акустических измерений. В то же время данные по влиянию отжига, полученные обоими методами, качественно согласуются между собой, в частности, наблюдается такое же по порядку величины уменьшение плотности дислокаций.

Ключевые слова: сильная пластическая деформация, ультрамелкозернистые металлы, акустическая спектроскопия, дифракция рентгеновских лучей, низкие температуры.

\section{Introduction}

It is well known that highly fragmented metals and alloys obtained by the methods of severe plastic deformation (SPD) have thermodynamically nonequilibrium defect structures, the transition of which to the equilibrium state determines the instability of their most important functional and operational properties (strength, ductility, elastic properties, etc.). This circumstance confines the wide use of ultrafine-grained (UFG) and nanostructured (NS) metals and alloys obtained by SPD method as structural materials for industry, in particular, as structural elements in aerospace engineering and nuclear power engineering intended for operation under extreme operating conditions with frequent heat exchanges and/or under significant mechanical loads $[1,2]$.

These factors determine the importance of studying the stability of the microstructure of NS and UFG materials obtained by SPD methods, caused by both external factors (temperature, applied mechanical stresses) and those resulting from incompleteness of processes that occur during SPD. In the SPD process, practically all modes of plastic flow are activated: slip and multiplication of dislocations in all available dislocation systems, twinning (including multiple), grain-boundary slippage, competition between the processes of strain hardening and dynamic recovery is also observed. As a result, a huge number of deformation defects are created in the material - dislocations, twins, high-angle grain boundaries, vacancies, and pores that all are in the fields of significant internal stresses created during SPD. The defect subsystem of UFG and NS metals is metastable, and in some cases non-equilibrium. External influences (temperature, applied alternating stresses, etc.) lead to a decrease in the density of dislocations, grain growth (recrystallization), vacancy annihilation, and, finally, contribute to relaxation of internal stresses.

Studying the influence of external factors on the stability of the properties of UFG metals provides valuable information on the evolution of their structure. In this work, the methods of acoustic spectroscopy and Xray structural analysis were used to study the effect of annealing on the parameters of the dislocation structure of ultrafine-grained FRTP (Fire Refining Tough Pitch) copper, obtained using the SPD methods including hydroextrusion (HE) and drawing (D). The parameters of the dislocation structure of the UFG copper were determined from the data on the low-temperature Bordoni dynamic relaxation caused by the thermally activated generation of kink pairs in dislocations. Parameters of the dislocation structure were also obtained by determining the coherent scattering regions (CSR) and microdistortions using $\mathrm{X}$-ray diffraction. From these data, estimates of the average dislocation density in samples were obtained.

It should be noted that when studying the dislocation subsystems of crystals, the acoustic and X-ray methods provide information on the characteristics of substantially different parts of the entire dislocation ensemble. In acoustic experiments, the vibrations of the longest and most favorably located relative to the external alternating 
stress mobile dislocations belonging to slip systems with a nonzero Schmid factor are excited. Accordingly, the parameters of a relatively small part of the moving dislocation segments are determined. In the X-ray measurements, on the contrary, the parameters of the dislocation subsystem are determined over the entire dislocation ensemble in the crystal. As a result, in the first case we get underestimated, and in the second case, overestimated data on the density of dislocations.

A comparative study of the change in the density of dislocations by X-ray and acoustic methods makes it possible to obtain information on changes in both the total density of the dislocation ensemble and the density of its most mobile part as a result of external impact. As the latter, in this work, isothermal annealing of samples at elevated temperatures was used.

\section{Experimental details}

2.1. Preparation and characteristics of samples. We studied samples of ultrafine-grained (UFG) technically pure fire-refined (FRTP) copper with a purity of $99.95 \%$ obtained as a result of combined severe plastic deformation (SPD) that includes multiple hot and cold hydrostatic extrusion (HE) and drawing (D) (for more details see [3]). The technological sequence of operations during the sample preparation is presented in Table 1. The total reduction of the starting material was $96.6 \%$, and the total deformation was $e_{\Sigma}=6.77$. The average grain size was decreased down to $\bar{d} \sim 200-300 \mathrm{~nm}$.

Table 2.

Sample preparation.

\begin{tabular}{|c|c|c|c|c|}
\hline $\begin{array}{c}\text { № } \\
/ \\
\text { № } \\
\end{array}$ & Procedure & $D, \mathrm{~mm}$ & $\begin{array}{c}\text { Reduction, } \\
\%\end{array}$ & $e_{\Sigma}$ \\
\hline 1. & Start of processing & 59 & 0 & 0 \\
\hline 2. & \multirow{3}{*}{ Hot extrusion } & 43 & 27.1 & 0.633 \\
\hline 3. & & 28 & 52.5 & 1.491 \\
\hline 4. & & 22.5 & 61.9 & 1.928 \\
\hline 5. & $\begin{array}{l}\text { Ageing at } 20^{\circ} \mathrm{C}, 10 \\
\text { months }\end{array}$ & 22.5 & 61.9 & 1.928 \\
\hline 6. & Hot extrusion & 18.8 & 68.1 & 2.287 \\
\hline 7. & Cold extrusion & 13 & 78.0 & 3.025 \\
\hline 8. & $\begin{array}{l}\text { Annealing at } 150 \\
{ }^{\circ} \mathrm{C}, 30 \mathrm{~min} .\end{array}$ & 13 & 78.0 & 3.025 \\
\hline 9. & \multirow{4}{*}{$\begin{array}{c}\text { Cold } \\
\text { hydroextrusion }\end{array}$} & 10 & 83.1 & 3.550 \\
\hline 10. & & 8 & 86.4 & 3.996 \\
\hline 11. & & 6 & 89.8 & 4.572 \\
\hline 12. & & 4 & 93.2 & 5.382 \\
\hline 13. & Drawing & 2 & 96.6 & 6.769 \\
\hline
\end{tabular}

$D$ is the diameter of the copper billet.

2.2. Acoustic measurements. Information on the dynamic characteristics of moving dislocations has been obtained by a detailed analysis of the parameters of the low-temperature Bordoni dislocation acoustic relaxation in copper [4-8]. Acoustic measurements were carried out by the two-component composite vibrator method [9]. In samples with a length of about $25 \mathrm{~mm}$ and a diameter of 2 $\mathrm{mm}$, longitudinal standing waves at frequencies $f \approx 73$ $\mathrm{kHz}$ were excited using a piezoelectric quartz transducer; in this case, the wave vector of ultrasound coincided with the direction of hydroextrusion and drawing. The temperature dependences of the logarithmic decrement $\delta$ $(T)$ and the dynamic Young's modulus $E(T)$ were measured in the temperature range $5-310 \mathrm{~K}$ in the amplitude-independent region with a constant amplitude of ultrasonic deformation $\varepsilon_{0} \approx 1 \cdot 10^{-7}$. The rate of temperature changes was $\sim 1 \mathrm{~K} / \mathrm{min}$.

2.3. X-ray measurements. To study the structure of polycrystalline materials, in particular, the sizes of coherent scattering regions and microstrains, there several X-ray techniques based on the analysis of the nature of the broadening of X-ray diffraction lines were developed. In this work, we used a method of an approximation of the shape of the X-ray line profile by standard broadening functions. The study was carried out using DRON-2.0 diffractometer in copper radiation with a $\mathrm{K} \alpha$ nickel filter. First, the parameters of the dislocation structure of the initial samples were studied immediately after the SPD procedure. Then the samples were annealed, and after each annealing, the measurement cycle was repeated. Processing of the obtained diffraction patterns was carried out according to the standard procedures [1012]. The broadening effects were separated graphically by plotting the Williamson-Hall graph. From the intercept on the ordinate axis, the average CSR size $\langle D\rangle$ was determined and from the slope of the graph the microstrain $\varepsilon$ was determined. Based on these data, the average values of the dislocation densities $\rho_{\mathrm{av}}$ were calculated.

2.4. Annealing procedure. After carrying out acoustic and X-ray measurements on the as-prepared samples, they were subjected to isothermal annealing with at elevated annealing temperatures in the temperature range $90^{\circ} \mathrm{C}<T_{\text {ann }}<430{ }^{\circ} \mathrm{C}$. Samples were annealed for $30 \mathrm{~min}$ in vacuum. The annealing temperature range was chosen in such a manner that the primary recrystallization temperature in highly deformed copper $T_{\mathrm{R}} \approx 135{ }^{\circ} \mathrm{C}$ fell into this interval. Because of the fact that the behavior of the dynamic Young's modulus $E$ in annealed samples prepared by hydroextrusion and drawing drastically differed from the behavior of $E$ in ECAP-treated copper $[3,13,14]$, the annealing temperature range was extended towards higher temperatures. The annealing temperature step was $20-50 \mathrm{~K}$ and depended on changes in the 
measured values as a result of annealing. After each annealing, the cycle of acoustic and X-ray measurements was repeated.

\section{Results and discussion}

Peak Bordoni. When studying the temperature dependences of the logarithmic decrement $\delta(T)$ in the samples of UFG copper, a pronounced peak of internal friction was found, localized at a temperature of $T_{\mathrm{P} 1} \approx 82$ $\mathrm{K}$ at an ultrasound frequency of $f \approx 73 \mathrm{kHz}$ (curve 1 in Fig.1a).

On the low-temperature side of this peak, a small satellite of the main peak was also observed at $T_{\mathrm{P} 2} \approx 35 \mathrm{~K}$. It was found that the temperatures of the peaks $T_{\mathrm{P} 1}$ and $T_{\mathrm{P} 2}$ increase with increasing the vibration frequency. This indicates that these peaks are due to thermally activated dynamic relaxation processes. For a simple Debye-type relaxation process with a single relaxation time, we can write

$$
\delta_{\mathrm{r}}=2 \delta_{\mathrm{r} \max } \frac{\omega \tau}{1+(\omega \tau)^{2}},
$$

where $\delta_{\mathrm{r}}$ is the relaxation component of the logarithmic decrement, $\omega=2 \pi f$ is the angular frequency.

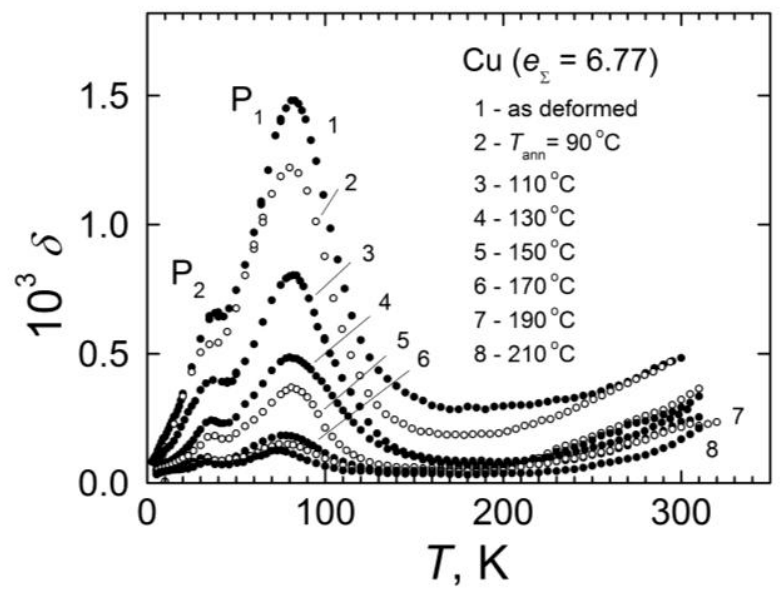

Fig. 1. Temperature dependences of the logarithmi decrement $\delta(T)$ in the FRTP copper sample immediatel after SPD with the total true strain $e_{\Sigma}=6.77$ (curve 1) an after a series of anneals at successively elevate temperatures (curves 2-8).

The relaxation contribution to the measured decrement $\delta_{\mathrm{r}}$ reaches its maximum value $\delta_{\mathrm{r} \text { max }}=\pi \Delta_{0} / 2$ at $\omega \tau\left(T_{\mathrm{P}}\right)=1$, $\Delta_{0}$ is the relaxation strength, $T_{\mathrm{P}}$ is the peak temperature. Since in this experiment the measurement frequency $f$ with temperature varies insignificantly, the temperature dependence $\delta_{\mathrm{r}}(T)$ is mainly determined by the temperature dependence of the relaxation time $\tau(T)$, which for thermally activated relaxation with activation enthalpy $H$ and an attempt period $\tau_{0}$ is described by the well-known Arrhenius' expression

$$
\tau(T)=\tau_{0} \exp (H / k T),
$$

here $k$ is the Boltzmann constant. Thus, the temperature dependence of the relaxation component of the logarithmic decrement may be represented as

$$
\delta_{r}(T) \approx \delta_{r \max } \operatorname{sech}\left\{\frac{H}{k}\left(\frac{1}{T}-\frac{1}{T_{P}}\right)\right\} .
$$

It should be noted that expression (3) is valid only for the relaxation processes with a single relaxation time and in the assumption $f=$ const). The activation enthalpy $H$ and the attempt period $\tau_{0}$ can be determined from measurements at several frequencies and then plotting $\ln (\omega)$ as a function of the inverse peak temperature $1 / T_{\mathrm{P}}$ :

$$
\ln \omega=\ln \left(\tau_{0}^{-1}\right)-\frac{H}{k} T_{\mathrm{p}}^{-1}(\omega)
$$

By measuring at the 1st, 3rd, and 5th harmonics of the quartz transducer fundamental frequency, the average values of the activation enthalpy $H$ and the attempt period $\tau_{0}$ were determined for the $\mathrm{P}_{1}$ and $\mathrm{P}_{2}$ peaks: $H_{1}=0.09 \mathrm{eV}$, $\tau_{01}=6 \cdot 10^{-12} \mathrm{~s}$ and $H_{2}=0.017 \mathrm{eV}, \tau_{02}=1 \cdot 10^{-9} \mathrm{~s}$, respectively. These values are close to the activation parameters of the Bordoni and Niblett-Wilks peaks earlier observed in single crystals and coarse-grained polycrystals of copper [7].

According to the well-established theoretical concepts of A. Seeger $[5,6]$, it can be argued that the peaks $\mathrm{P}_{1}$ and $\mathrm{P}_{2}$ are caused by the thermally activated motion of dislocations in the Peierls' potential reliefs of the first and second order. The microscopic mechanism responsible for the appearance of the $\mathrm{P}_{1}$ peak is the thermally activated nucleation of kink pairs in dislocation lines (overcoming Peierls' potential barriers of the first order). The lowtemperature peak $\mathrm{P}_{2}$ may be the resulted by thermally activated diffusion of geometric kinks in dislocations in the secondary Peierls' relief.

Annealing of samples of the UFG copper at temperatures lower and higher than the primary recrystallization temperature led to substantial changes in the parameters of the dynamic Bordoni relaxation (see Figs. 1, 2 a,b). 


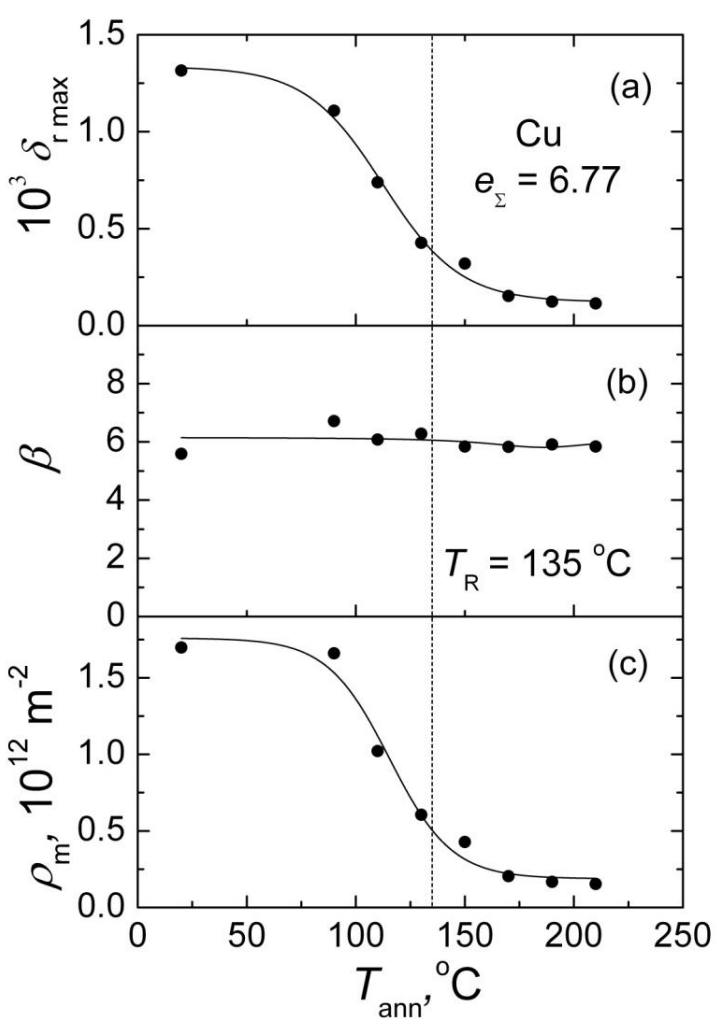

Fig. 2. The effect of annealing on (a) the height $\delta_{\mathrm{r} \max }$ of the Bordoni peak, (b) the parameter of the distribution $\beta$ of the relaxation time (peak width, see text) and (c) the mobile dislocations density $\rho_{\mathrm{m}} . T_{\mathrm{R}}$ is the primary recrystallization temperature of highly deformed copper.

First of all, a significant and systematic decrease in the height of the relaxation component of the $P_{1}$ peak with increasing annealing temperature $T_{\text {ann }}$ should be noted (Fig. 2a). It is known that the height of the dynamic relaxation peaks is determined by the product of the number of acting elementary relaxation entities and their individual contribution to the relaxation. For the Bordoni peak, it was shown [4] that the upper limit of its height $\delta_{\mathrm{r}}$ ${ }_{\text {max }}$ is determined by the expression

$$
\delta_{\mathrm{r} \max }=\frac{\pi L^{2} \rho_{\mathrm{m}}}{24}
$$

here $L$ is the average length of the dislocation segments and $\rho_{\mathrm{m}}$ is the density of mobile dislocations contributing to the dynamic relaxation. This allows one to obtain with certain omissions an estimate of the dislocation density:

$$
\rho_{\mathrm{m}}=\frac{24 \delta_{\mathrm{r} \max }}{\pi L^{2}}
$$

It should be noted that the use of the experimentally observed $\delta_{\mathrm{r} \max }$ in the expression (6) leads to a very underestimated value of the dislocation density. This is Вісник ХНУ імені В.Н. Каразіна, серія «Фізика», вип. 30, 2019 due to the fact that the observed peaks of dynamic relaxation often turn out to be much wider than expression (1) predicts for Debye-type relaxation with a single $\tau$ [8]. The broadening of the relaxation peak is accompanied by a decrease in its height and may have various reasons, among which one of the main ones is the presence of a spectrum of relaxation times $\tau$, due to the existence of nonequivalent conditions for the motion of elementary relaxators in a real crystal. The mechanism of broadening of peaks and a decrease in their height due to a spread in relaxation times was considered in detail by Nowick and Berry [8], who used the Gaussian distribution of the variable $z=\ln \left(\tau / \tau_{\mathrm{m}}\right)$, where $\tau_{\mathrm{m}}$ is the average relaxation time at a given temperature. The probability density of this distribution is

$$
\Phi(z)=\frac{\exp \left\{-(z / \beta)^{2}\right\}}{\beta \sqrt{\pi}},
$$

here $\beta$ is a parameter characterizing the width of the distribution of the relaxation time (for $z=\beta$ the value $2 \beta$ is equal to the width of the distribution at a relative height $1 / e)$. Taking into account the distribution of $\tau$, expression (3) takes the form:

$$
\delta_{\mathrm{r}}=\frac{\delta_{r \max }}{\sqrt{\pi}} \int_{-\infty}^{\infty} \exp \left[-u^{2}\right] \operatorname{sech}(x+\beta u) d u,
$$

where $u=z / \beta, x=\ln \left(\omega \tau_{\mathrm{m}}\right)$ (if in the experiment the oscillation frequency varies at a constant temperature) or

$$
x=\frac{H}{k}\left(\frac{1}{T}-\frac{1}{T_{\mathrm{P}}}\right)
$$

in the case when in the experiment changes the temperature but the oscillation frequency remains almost constant.

For $\beta>0$, the width of the experimentally observed peak increases and the height decreases. This should be taken into account when treating the results of the experiment in order to obtain quantitative information on parameters of the elementary relaxators (in particular, the parameters of the dislocation subsystem). Empirical expressions were obtained in [15] for dynamic relaxations of the Debye and Koiwa-Hasiguti types which allow one to determine from the experiment the values of $\beta$ and a corresponding decrease in the height of the relaxation peak. By numerical methods, a relationship was established between $\beta$ and the ratio $r$

$$
\beta=(r-1)^{0.366}+1.493(r-1),
$$




$$
r=\frac{\Delta\left(1 / T_{0.5}^{\mp}\right)(\beta)}{\Delta\left(1 / T_{0.5}^{\mp}\right)(0)} .
$$

Here $\Delta\left(1 / T_{0.5}^{\mp}\right)(0)$ and $\Delta\left(1 / T_{0.5}^{\mp}\right)(\beta)$ are the peak widths when $\beta=0$ and $\beta>0$, respectively. The width of the Debye peak can be determined from the expression [7]:

$$
\Delta\left(1 / T_{0.5}^{\mp}\right)(0)=2.725 \mathrm{k} / \mathrm{H} .
$$

The decrease in the height of the Debye peak with an increase in $\beta$ is described by the expression

$$
\delta_{\mathrm{r} \max }(\beta)=\delta_{\mathrm{r} \max }(0)\left(0.05+\frac{0.45}{1+0.233 \beta^{1.59}}\right)
$$

and should be taken into account when determining the dislocation density by the height of the Bordoni peak. In Fig. $2 b$, the dependence of $\beta$ on the annealing temperature $T_{\text {ann }}$ is shown, and in Fig. 2c the density of mobile dislocations is presented which was obtained taking into account expression (13). It is appropriate to note here that the height of the Bordoni peak in UFG copper obtained by equal channel angular pressing (ECAP) [14] turned out to be several times higher than in the present work. This may indicate that, when using ECAP, the dynamic recovery processes are less intensive than during hydroextrusion and drawing and a higher dislocation density is created in the samples.

In addition to the dislocation density, the study of the Bordoni relaxation can provide important experimental information on other parameters of the dislocation structure of the metal under study, in particular, on the characteristics of the interaction of dislocations with the crystal lattice and overcoming by moving dislocations the Peierls' potential relief.

According to Seeger's theory and its subsequent modifications $[4,6,7]$, the activation enthalpy $H$ of the Bordoni peak is approximately equal to the energy required for the formation of a pair of kinks of opposite signs at the dislocation

$$
H \simeq 2 W_{k},
$$

where $W_{\mathrm{k}}$ is the energy of a single kink formation equal to

$$
W_{k}=\frac{4 a_{\mathrm{P}}}{\pi}\left(\frac{C a_{\mathrm{P}} b \tau_{\mathrm{P}}}{2 \pi}\right)^{1 / 2} \text {. }
$$

Here $C=G b^{2} / 2$ is the linear energy of the dislocation, $a_{\mathrm{P}}$ is the period of the Peierls' potential relief, $b$ is the module of the Burgers vector, $G$ is the shear modulus, and $\tau_{\mathrm{P}}$ is the Peierls stress calculated in terms of a simple model (Peierls' sinusoidal potential) without taking into account thermal activation and quantum effects. Using (14) and (15), an estimate of the Peierls' stress for the UFG copper was obtained:

$$
\tau_{\mathrm{P}}=\frac{\pi^{3} H^{2}}{16 a_{\mathrm{P}}^{3} b^{3} G}=19 \mathrm{M \Pi а} \approx 2.5 \cdot 10^{-4} G
$$

When calculating with (16), the following values were used: $H=0.09 \mathrm{eV}, a_{\mathrm{P}} \approx b=2.56 \cdot 10^{-10} \mathrm{~m}, G=75.5 \mathrm{GPa}$.

3.2. $X$-ray diffraction analysis. The results of $X$-ray diffraction measurements are shown in Fig. 3.

Fig. 3a shows the changes in the lattice parameter $a$ of UFG copper during annealing. Annealing leads to an increase in the lattice parameter by $1.2 \%$ in the range of annealing temperatures near $150{ }^{\circ} \mathrm{C}$ with a subsequent exit to the plateau starting from $T_{\text {ann }} \approx 200{ }^{\circ} \mathrm{C}$. It should be noted that the value of $a$ in the SPD treated samples is noticeably lower, and in the annealed samples it is noticeably higher than in the samples of coarse-grained well-annealed copper. The reason may be the presence of internal stress fields created during SPD processing and their evolution during annealing (see Fig. 3 b).

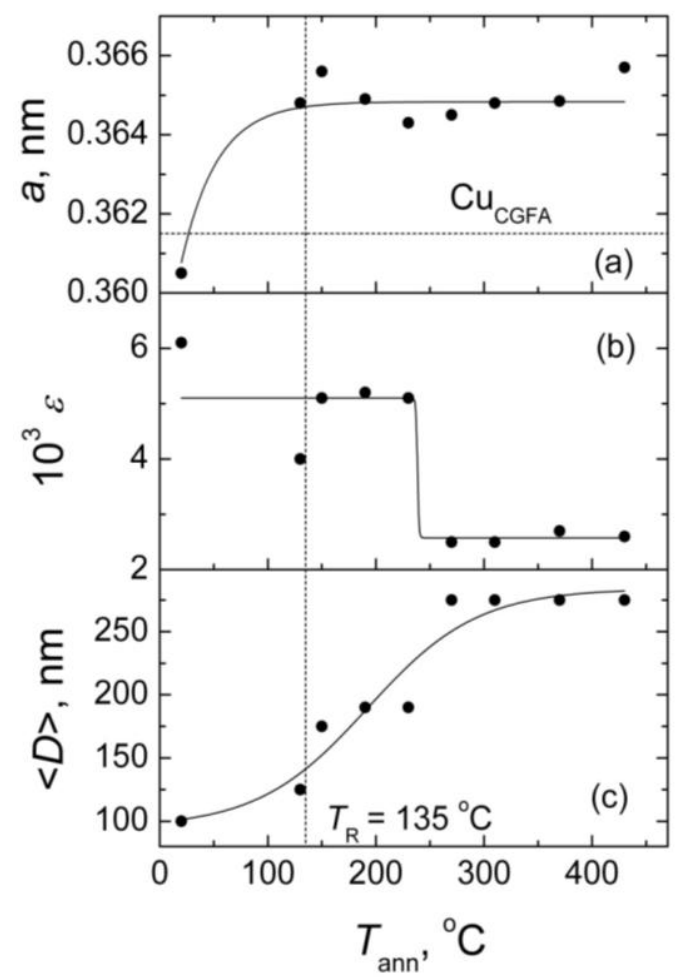

Fig. 3. The effect of annealing on: (a) the lattice parameter $a$, (b) microdistortion $\varepsilon$ in the lattice, (c) the mean CSR diameter $\langle D\rangle$. The horizontal dashed line shows the value of $a$ in coarse-grained fully annealed copper and the vertical one shows the temperature of primary crystallization of highly deformed copper.

Calculated X-ray parameters, the microstrains $\varepsilon$ (Fig. $3 \mathrm{~b}$ ) and the mean size of CSR $\langle D\rangle$ (Fig. 3c), show that 
the SPD technology used for wire producing leads to high microstrains $\left(\varepsilon \approx 6 \cdot 10^{-3}\right.$ ) and small values of the CSR (domain size is about $100 \mathrm{~nm}$ at the average grain size of $200 \mathrm{~nm}$.). As a result of sample annealing, the microstrains decrease and the mean size of CSR increases. First may be due to both lowering dislocation density as well as to recrystallization processes at annealing temperatures $T_{\mathrm{ann}}>T_{\mathrm{R}}$. The latter is caused mainly by recrystallization. As it was established in [3], copper wires prepared by hydroextrusion and drawing have strong crystallographic texture that significantly changes during annealing at $T_{\mathrm{ann}}>T_{\mathrm{R}}$.

The integrated average dislocation density $\rho_{\mathrm{av}}$ obtained from the X-ray diffraction experiments appears to be almost 2 orders of magnitude higher than the density of mobile dislocations $\rho_{\mathrm{m}}$ given by the acoustic spectroscopy method (Fig. 4).

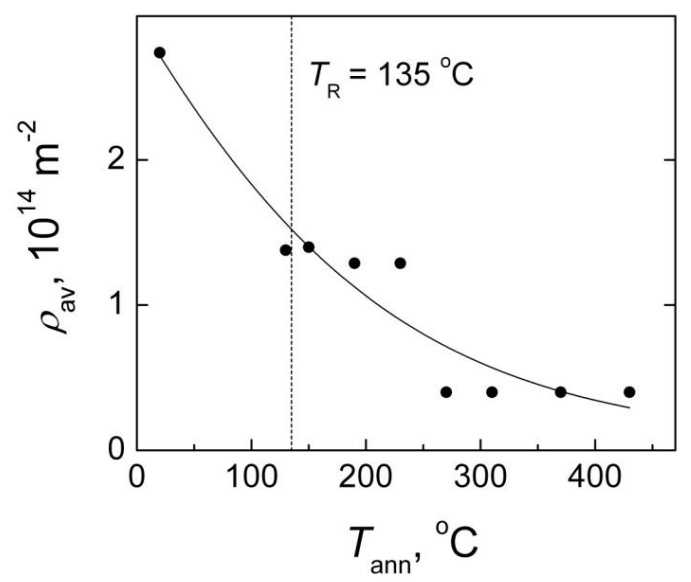

Fig. 4. Change in the average dislocation density in the samples of UFG copper obtained by X-ray diffraction. The dashed line shows the primary crystallization temperature of highly deformed copper.

In addition, the temperature range, in which the most intensive changes in the dislocation density occurs, in the $\mathrm{X}$-ray experiment is shifted by $30-40{ }^{\circ} \mathrm{C}$ towards higher temperatures. However, it can be argued that the data on the effect of annealing on the dislocation density obtained by both methods are in qualitative agreement with each other; in particular, a decrease in the dislocation density of the same order of magnitude is observed.

\section{Conclusions}

1. Acoustic spectroscopy and X-ray diffraction methods have been used to study the effect of annealing on the parameters of the dislocation structure of the UFG copper obtained by hydroextrusion and drawing. Annealing was carried out in the temperature range 90 $430{ }^{\circ} \mathrm{C}$, including the primary recrystallization temperature of highly deformed copper $T_{\mathrm{R}} \approx 135{ }^{\circ} \mathrm{C}$.

2. From acoustic measurements, an estimate of the density of mobile dislocations $\rho_{\mathrm{m}}$ which contribute to the low-temperature dynamic relaxation of Bordoni was obtained. It turned out to be 5 times lower than in the UFG samples of copper obtained using equal channel angular pressing (ECAP).

3. As a result of annealing, the density of mobile dislocations decreases by almost an order of magnitude. The most intense decrease in $\rho_{\mathrm{m}}$ occurs at annealing temperatures near the primary recrystallization temperature of highly deformed copper.

4. From acoustic measurements, an estimate of the 1st order Peierls' stress in copper was also obtained: $\tau_{\mathrm{P}}=19 \mathrm{MPa} \approx 2.5 \cdot 10^{-4} G$.

5. In parallel with the acoustic measurements, the average integral dislocation density $\rho_{\mathrm{av}}$ of the annealed samples was investigated by X-ray diffraction, which turned out to be two orders of magnitude larger than the value $\rho_{\mathrm{m}}$ obtained from acoustic measurements.

6. Despite the quantitative difference, the data on the effect of annealing on the dislocation density obtained by both methods are in qualitative agreement with each other, in particular, with an increase in the annealing temperature, a decrease in the dislocation density of the same order of magnitude is observed.

\section{References}

1. Y. Estrin, A. Vinogradov. Acta Mater., 61, 782 (2013).

2. T.G. Langdon. Acta Mater., 61, 7035 (2013).

3. P.P. Pal-Val, Yu.N. Loginov, S.L. Demakov, A.G. Illarionov, V.D. Natsik, L.N. Pal-Val, A.A. Davydenko, A.P. Rybalko. Mater. Sci. \& Eng., A618, 9 (2014).

4. D. Niblett. Pik Bordoni $\mathrm{v}$ graneczentrirovanny'kh kubicheskikh metallakh. V kn. Fizicheskaya akustika, red. U. Me`zon, Mir, M. (1969), t. III, ch. A., s. 99.

5. A. Zeger, P. Shiller. Peregiby' na dislokacziyakh i ikh vliyanie na vnutrennee trenie $\mathrm{v}$ kristallakh. $\mathrm{V}$ kn. Fizicheskaya akustika, red.U. Me`zon, Mir, M. (1969), t. III, ch. A. s. 428.

6. A. Seeger. J. de Phys. Colloq., 32 (C2), C2-193 (1971).

7. R. De Batist. Internal Friction of Structural Defects in Crystalline Solids, North Holland, Amsterdam (1972), 477 p.

8. A. Novik, B. Berri. Relaksaczionny`e yavleniya v kristallakh, Atomizdat, M. (1975), $472 \mathrm{c}$.

9. V.D. Natsik, P.P. Pal-Val, S.N. Smirnov. Acoust. Phys., 44, 553 (1998).

10. G.K. Williamson, W.H. Hall. Acta Met., 1, 22 (1953).

11. L.I. Mirkin. Spravochnik po rentgenostrukturnomu analizu polikristallov, Fizmatizdat, M. (1961), $862 \mathrm{~s}$.

12. L.S. Palatnik. Struktura i fizicheskie svojstva tverdogo tela, Vishha shkola, K. (1983), $264 \mathrm{~s}$.

13. P.P. Pal-Val , L.N. Pal-Val. Metal Sci. Heat Treatment., 54, 234 (2012).

14. I.S. Golovin, P.P. Pal-Val, L.N. Pal-Val, E.N. Vatazhuk, Y. Estrin. Solid State Phenom.,184, 289 (2012).

15. P.P. Pal-Val , L.N. Pal-Val, A.P. Rybalko, E. N. Vatazhuk. Adv. Mater. Sci. Eng., 2018, 4170187 (12 p.) (2018). 